\title{
PENGARUH MODEL PEMBELAJARAN COOPERATIVE LEARNING TIPE GROUP INVESTIGATION (GI) DAN MOTIVASI BELAJAR TERHADAP KEMAMPUAN MENULIS TEKS CERITA FANTASI SISWA KELAS VII SMP NEGERI 21 PALEMBANG
}

\author{
Yulisar Panuah \\ SMP Negeri 21 Palembang \\ yulisarpanuah@gmail.com
}

\begin{abstract}
Abstrak
Penelitian ini bertujuan untuk mengetahui pengaruh model pembelajaran cooperative learning tipe group investigation (GI) dan motivasi belajar terhadap kemampuan menulis teks cerita fantasi siswa kelas VII Smp Negeri 21 palembang. Teknik pengumpulan data menggunakan teknik tes, sedangkan teknik analisis data menggunakan statistik dengan uji t. Hasil dalam penelitian ini pertama model pembelajaran cooperative learning tipe group investigation berpengaruh terhadap kemampuan menulis teks cerita fantasi siswa kelas VII SMP Negeri 21 Palembang. Hal ini terbukti dari hasil pengujian hipotesis diperoleh bahwa nilai sig (2-tailed) sebesar 0,000. Karena nilai sig (probabilitas) lebih kecil dari 0,025, maka Ha diterima. Kedua motivasi belajar berpengaruh terhadap kemampuan menulis teks cerita fantasi siswa kelas VII SMP Negeri 21 Palembang. Hal ini terbukti dari hasil pengujian hipotesis diperoleh bahwa nilai sig (2-tailed) sebesar 0,020 Karena nilai sig (probabilitas) lebih kecil dari 0,025, maka Ha diterima. Ketiga Model Pembelajaran cooperative learning tipe group investigation dan motivasi belajar berpengaruh terhadap kemampuan menulis teks cerita fantasi siswa kelas VII SMP Negeri 21 Palembang. Hal ini terbukti dari hasil pengujian hipotesis diperoleh bahwa nilai probabilitas interaksi Model Pembelajaran cooperative learning tipe group investigation dan motivasi $(0,024)<0,05$; maka Ho ditolak dan Ha diterima.
\end{abstract}

\section{Kata kunci : Cooperative Learning, Group Investigation dan Cerita Fantasi}

\section{PENDAHULUAN}

Pendidikan salah satu bagian dan pilar terpenting bagi setiap insan manusia dalam mempertajam dan memperkuat benteng diri. Setiap insan manusia wajib mengenyam pendidikan karena manusia yang memiliki jenjang pendidikan biasanya adalah insan yang maju dalam mengatur dan mengontrol pola pikir untuk menjadi lebih baik.

Proses dalam sebuah pendidikan tidak terpisahkan dari sebuah pembangunan dalam hal mengembangkan pribadi yang memiliki 
kualitas. Selain itu pendidikan itu sendiri ialah pengubahan sikap atau tindak laku seorang individual dalam upaya mendewasakan diri dengan upaya pengajaran dan pelatihan. Ada beberapa hal yang dapat menjadi faktor yang mempengaruhi peserta didik diantaranya bakat dan juga lingkungan. Bakat dalam hal ini sangat menjadi pengaruh didalam diri manusia karena setiap insan berpacu kepada keinginan dalam menyambut masa depan sehingga manusia tersebut sudah memiliki gambaran atau tujuan hidup yang dia inginkan melalui sebuah bakat.

Faktor berikutnya yaitu lingkungan, lingkungan menjadi bagian penting dalam hal membentuk karakter seseorang jika lingkungan baik bisa jadi atau berkemungkinan jiwa atau diri manusia akan menjadi baik begitu sebaliknya.

Artinya pendidikan dapat dikatakan sebagai proses pengajaran dan pelatihan yang mampu membuat diri manusia menjadi manusia yang memiliki kualitas dan sikap mandiri yang baik dari segi pengetahuan atau bahkan orang lain yang berada disekitarnya.

Dipandang dari segi proses, pendidikan ialah perilaku dalam hal mempengaruhi seorang peserta didik. Hal ini diharapkan agar seorang peserta didik bisa menyesuaikan diri sebaik mungkin dengan lingkungannya.

Pendidikan di negeri kita Indonesia sangatlah maju apalagi pada era sekarang dimana teknologi memiliki peran tersendiri dalam sebuah proses pembeljaran, hal ini dapat dibuktikan dengan makin banyaknya seorang pendidik menggunakan media-media pembelajaran yang erat kaitanya dengan perkembangan teknologi.

Mutu atau kualitas pendidikan pada hakikatnya sangat erat kaitannya dengan kompetensi seorang pendidik dalam mengajar oleh karena itu tenanga pendidik adalah komponen terpenting diselenggarakanya pendidikan itu, karena pendidik memiliki tugas mewujudkan kegiatan pengajaran, pelatihan, penelitian, mengembangkan, mengelola dan memberikan pelayanan teknis dalam bidang pendidikan.

Menurut Hamalik (2015:9) dipandang sebagai orang yang terlibat dan memegang peranan penting pendidik juga dituntut untuk pandai dalam menerapkan berbagai model pembelajaran dan pendekatan mengajar juga terampil dalam menggunakan alat peraga. Dengan kata lain kualitas pembelajaran tergantung pada kemampuan pendidik dalam memadukan secara sistematis dan sinergis pendidik, kurikulum, bahan ajar, media, fasilitas, sistem, pembelajaran dalam menghasilkan proses belajar yang optimal.

Karena pentingnya kita sebagai pendidik dalam hal menguasai model pembelajaran sebagai hal yang dapat menunjang proses belajar, maka peneliti dalam hal ini berupaya untuk menerapkan model pembelajaran yang tepat untuk pelajaran Bahasa Indonesia. Peneliti telah melakukan observasi dalam rana ini untuk mengetahui dan meninjau langsung kondisi sesungguhnya dari sekolah yang akan menjadi tempat dilaksanakan penelitian dan juga kelas yang menjadi objek dalam sebuah penelitian.

Berdasarkan hasil wawancara dengan wakil kurikulum dan juga guru Bahasa Indonesia didapatkan bahwa SMP 21 Palembang memiliki rentang kriteria ketuntasan minimum sebear 65 sebagai minimum tuntas atau tidaknya siswa dalam sebuah pembelajaran. Peneliti menjelaskan bahwa akan mengadakan proses evaluasi atau peninjauan hasil karya tulis peserta didik.

Menulis merupakan salah satu keterampilan berbahasa yang memiliki tujuan sama yaitu 
menyampaikan informasi namun dilakukan secara tidak langsung dalam hal ini menggunakan media lain. Materi menulis teks cerita fantasi terdapat dalam kompetensi dasar (KD) 4.4 menyajikan gagasan kreatif dalam bentuk cerita fantasi secara lisan dan tulis dengan memperhatikan struktur dan penggunaan bahasa.

Dengan indikator pencapaian kopentensi pada 4.4.2 Menulis cerita fantasi dengan memperhatikan pilihan kata, kelengkapan struktur, dan kaidah penggunaan kata kalimat/ tanda baca/ejaan.

Teks cerita fantasi merupakan bagian dari teks narasi karena diciptakan dalam bentuk rangkaian atau peristiwa yang disebut. (Kemendibud 2016:50) menyatakan bahwa teks cerita fantasi adalah cerita fiksi yang memanfaatkan unsur imajinasi dan fantasi sehingga membuat cerita lebih menarik.

Teks cerita fantasi mencoba menghadirkan sebuah dunia lain disamping dunia nyata melalui sebuah imajinasi lazim dan dapat diterima oleh pembaca. Oleh karena itu, latar yang digunakan dalam cerita fantasi dapat berupa tempat yang bisa ditemukan di dunia nyata, tempat-temapat misterius, asing, angkasa, bahkan tempat-tempat yang tidak dapat diakses.

Penelitian ini mengguanakan model pembelajaran cooperative learning tipe group investigation dalam hal meninjau kemampuan siswa dari segi kemampuan menulis dan juga pemberian motivasi belajar terhadap siswa dalam ketercapaian nilai.

Cooperative learning adalah model pembelajaran siswa dibentuk dalam jangkauan kelompok kecil yang mempunyai tingkatan berbeda. Kooperatif sendiri pembelajaran kelompok yang diorganisir oleh suatu prinsip bahwa pembelajaran harus didasarkan perubahan informasi secara sosial diantara bagian kelompok belajar.

Cooperative learning tipe group investigation adalah model pembelajaran berkelompok dimana siswa diminta untuk meninjau atau menginvestigasi sebuah materi pembelajaran dalam hal ini cerita fantasi. Kemudian mereka akan membahas hasil investigasi yang telah dilakukan sehingga siswa dapat menganalisis hasil dari investigasi. Pendidik dalam hal ini berperan sebagai fasilitas yang menjadi penengah dalam kegiatan pembelajaran.

Motivasi dalam proses ini digunakan dalam menunjang atau bahkan dapat menggugah diri siswa untuk menjadi terpacu melakukan hal yang positif. Sehingga dapat meningkatkan kualitas penilaian peserta didik.

Pada penelitian ini peneliti ingin melihat sejauh mana model pembelajaran ini dapat berpengaruh kepada hasil proses belajar yang dilakukan siswa khususnya pada kemampuan menulis teks cerita fantasi.

Karena menulis sendiri salah satu keterampilan yang sangat sulit dikuasai oleh anak, apalagi jika dalam urusan mengarang sebuah cerita khususnya narasi dimana siswa masih memiliki kemampuan yang kurang dalam hal menulis.

Hal inilah yang membuat peneliti tergugah untuk meneliti kemampuan menulis, karena peniliti ingin melihat bagaiman respon peserta didik jikalau mereka diminta untuk menulis sebuah karangan khususnya karangan cerita fantasi.

Dan juga peneliti meyakini bahwa model pembelajaran ini dapat memberikan pengaruh khususnya dalam pembelajaran menulis teks cerita fantasi.

Ditinjau dari sebuah latar belakang inilah peneliti tertarik untuk melakukan sebuah 
kegiatan meneliti terkait judul " pengaruh model pembelajaran cooperative learning tipe group investigation dan motivasi belajar terhadap kemampuan menulis teks cerita fantasi siswa kelas VII SMP Negeri 21 Palembang" yang memusatkan keinginan meninjau tercapainya sebuah kegitan dalam hal penguasaan keterampilan tulis siswa.

\section{KERANGKA TEORITIK}

\section{A. Kemampuan Menulis Teks Cerita Fantasi}

\section{a) Kemampuan}

Semua anak diberikan kemampuan dengan ukuran dan kaasitas yang beragam. Antara manusia yang satu dengan yang lainya memiliki kemampuan yang berbeda. Beberapa orang pasti mempunyai jenjang kemampuan yang lebih tinggi. Sebagian lagi memiliki kekurangan pada beberapa kemampuan.

Kemampuan memiliki arti manusia itu sendiri sanggup dalam melakukan sesuatu yang terkait dengan tindakan. Dalam KBBI (2008:869) dijelaskan pengertian dari kemampuan adalah kesanggupan, kecakapan, kekuatan. Menurut Sternberg (dikutip Wardarita 2014:13) kemampuan berarti kekutan untuk menunjukan suatu tindakan khusus atau tugas khusus, baik secara fisik maupun mental.

\section{b) Menulis}

Menurut Tarigan (2008:3) menulis itu sendiri ialah keterampilan berbahasa yang di pergunakan untuk berkomunikasi secara tidak langsung, tidak secara tatap muka dengan orang lain.

\section{c) Pembelajaran Menulis Teks Cerita Fantasi}

Cerita fantasi dalah bagian dari sebuah karangan narasi, Dalman (2018:105) narasi adalah cerita yang jalan ceritanya berdasarkan urutan suatu atau serangkaian kejadian atau peristiwa.

\section{B. Model Pembelajaran Cooperative}

\section{a) Model Pembelajaran}

Mils dalam Suprijono (2013:45) menyatakan model ialah tampilan tepat sebagai proses aktual yang memungkinkan seseorang atau sekelompok orang mencoba bertindak berdasarkan model itu. Model merupakan interprestasi terhadap hasil observasi dan pengukuran yang diperoleh dari beberapa sistem.

\section{b) Cooperative Learning}

Menurut Shoimin, 2014:45 Cooperative learning merupakan suatu model pembelajaran yang mana siswa belajar dalam kelompokkelompok kecil yang memiliki tingkat kemampuan berbeda.

\section{c) Group Investigation (GI)}

Firiana (2010) menjelaskan model pembelajaran ini dikembangkan oleh Sharan \& Sharan pada tahun 1970. Model Group Invesigation merupakan salah satu pendekatan yang paling kompleks dan paling sulit diterapkan, bila dibandingkan dengan model STAD dan Jigsaw.

\section{Motivasi belajar siswa}

a. Pengertian Motivasi

Donald (dalam Sardiman 2014:73) menjelaskan definisi motivasi merupakan perubahan energi dalam diri seseorang yang ditandai dengan munculnya "feeling" dan didahului dengan tanggapan terhadap adanya tujuan.

\section{METODE PENELITIAN}

Mentode yang peneliti gunakan dalam proses ini ialah penelitian eksperimen. Menurut Sugiyono (2016:107), menjelaskan metode eksperimen merupakan metode penelitian ini bertujuan dalam mencari keterlibatan langsung suatu model pembelajaran kedalam suatu proses belajar. 
Sedangkan jenis eksperimen peneliti menggunakan pendekatan true experimental design (eksperimen murni).

Sugiyono (2016:112) juga mengemukakan, ciri utama pendekatan true experimental design adalah sampel yang digunakan secara random dari populasi tertentu. Jadi ciri-cirinya adalah adanya kelompok kontrol dan sampel dipilih secara random. Dalam true experimental design ada dua bentuk yaitu: Posttest Only Control Desaign dan Pretes-Posttest Group Design.

Dalam dua bentuk penelitian tersebut, peneliti memilih bentuk Posttest Only Control Design. Penelitian ini melibatkan dua kelompok yang diberi perlakuan berbeda antara kelompok eksperimen dengan kelompok kontrol. Kelompok yang dipilih berdasarkan pertimbangan tersebut, kemudian diberi posttest untuk mengetahui keadaan setelah diberikan materi tentang puisi, adakah perbedaan antara kelompok eksperimen (menggunakan model pembelajaran cooperative tipe round table) dengan kelompok kontrol (tanpa menggunakan model pembelajaran cooperative tipe round table). Rancangan atau desain penelitian yang digunakan adalah posttest-only control design. Desain tersebut digambarkan sebagai berikut.

\begin{tabular}{|ccc|}
\hline $\mathbf{R}$ & $\mathbf{X}$ & $\mathbf{O}_{2}$ \\
$\mathbf{R}$ & - & $\mathbf{O}_{4}$ \\
\hline
\end{tabular}

Gambar1. Desain eksperimen Posttest-Only Control Design

Keterangan :

$\mathrm{R}=$ kelompok kelas yang menjadi objek penelitian

$X=$ model pembelajaran cooprative tipe group investigation dan motivasi belajar siswa

$\mathrm{O} 2$ = Posttest kelompok eksperimen

$\mathrm{O} 4$ = Posttest kelompok kontrol

HASIL PENELITIAN DAN PEMBAHASAN a. Model pembelajaran cooperative

learning tipe group investigation

berpengaruh terhadap kemampuan

menulis teks cerita fantasi siswa kelas

VII SMP Negeri 21 Palembang

Penelitian ini dilakukan pada dua kelas sampel, yang diperoleh dari teknik pengambilan sampel Cluster sampling, random dilakukan atas dasar himpunan atau kelompok, dimana kelas VII.9 sebagai kelas eksperimen dan kelas VII.2 menjadi kelas kontrol. Yang menjadi kelas eksperimen diberikan perlakuan menggunakan model pembelajaran cooperative learning tipe group investigation dan motivasi belajar dan sebagai kelas kontrol yang hanya diajarkan dengan menggunakan metode ceramah atau konvensional.

Metode penelitian yang digunakan dalam penelitian ini adalah metode eksperimen. Sedangkan jenis eksperimen peneliti menggunakan true experimental design dengan bentuk posttest only control design. Dalam pemilihan penggunaan metode tersebut bertujuan untuk melihat pengaruh hasil belajar siswa pada kelas sampel. Peneliti mengharapkan adanya perbedaan hasil pembelajaran siswa kelas eksperimen dan siswa kelas kontrol. Pada kelas eksperimen dalam hal ini kelas VII.9 pembelajaran dilaksanakan dua kali pertemuan. Dimana pertemuan akhir dilaksanakan tes menulis teks cerita fantasi.

Pada kelas eksperimen diberikan perlakuan dengan menggunakan model pembelajaran cooperative learning tipe group investigation dan motivasi belajar sehingga dapat terjadinya peningkatan proses enilaian menulis pada teks cerita fantasi.

Hasil analisis data diperoleh memberikan pengaruh yang sangat signifikan antara nilai kemampuan menulis teks cerita fantasi antara 
siswa yang memperoleh pembelajaran dengan model pembelajaran cooperative learning tipe group investigation dan pendekatan konvensional. Artinya pembelajaran menulis teks cerita fantasi siswa yang memperoleh pembelajaran menggunakan model pembelajaran cooperative learning tipe group investigation lebih baik dibandingkan dengan pembelajaran dengan pendekatan konvensional.

Pembelajaran menulis teks cerita fantasi dengan menggunakan Model pembelajaran cooperative learning tipe group investigation memberikan kontribusi bagi siswa dalam memahami konsep materi yang diberikan sehingga kemampuan menulis teks cerita fantasi siswa bisa dikatakan baik. Hal ini disebabkan pada dasarkan Model pembelajaran cooperative learning tipe group investigation menekankan pentingnya siswa membangun diri sendiri pengetahuan mereka lewat keterlibatan aktif proses belajar mengajar.

\section{b. Motivasi belajar berpengaruh terhadap}

kemampuan menulis teks cerita fantasi

\section{siswa kelas VII SMP Negeri 21 Palembang}

Hasil analisis data didapatkan Motivasi belajar berpengaruh terhadap kemampuan menulis teks cerita fantasi siswa kelas VII SMP Negeri 21 Palembang. Hal ini berarti bahwa motivasi belajar tinggi mampu mempengaruhi kemampuan menulis teks cerita fantasi siswa. Hal tersebut dikarenakan siswa yang memiliki motivasi belajar tinggi lebih untuk menulis teks cerita fantasi dengan optimal.

\section{c. Model Pembelajaran cooperative learning tipe group investigation dan motivasi belajar berpengaruh terhadap kemampuan menulis teks cerita fantasi siswa kelas VII SMP Negeri 21 Palembang}

Hasil analisis data menunjukkan bahwa terdapat pengaruh interaksi antara Model Pembelajaran cooperative learning tipe group investigation dan motivasi belajar siswa terhadap kemampuan menulis teks cerita fantasi siswa kelas VII SMP Negeri 21 Palembang.

Hal ini dapat diartikan bahwa motivasi belajar dan modrel pembelajaran yang digunakan saling berkaitan erat dalam memberikan hasil yang signifikan terhadap kemampuan menulis teks cerita fantasi siswa sehingga hipotesis yang diajukan telah teruji kebenarannya.

Selain itu, pembelajaran dengan menggunakan Model Pembelajaran cooperative learning tipe group investigation melibatkan negoisasi (pertukaran pikiran) dan interprestasi yang dapat dilakukan antara murid dengan guru, atau antar sesama siswa. Mengkonstruksi pengetahuan baru dapat dilakukan siswa secara individual maupun dalam kelompok diskusi.

Diskusi sendiri dirasa sangat berpengaruh dalam sebuah peningkatan proses belajar, karena dengan diskusi biasanya mereka akan cenderung lebih aktif dalam memecahkan suatu permasalah dalam suatu materi belajar karena mereka jika dalam kelompok dapat langsung ikut serta bertukar pendapat saling memberikan masukan satu dengan lain. Sehingga siswa tidak terkukuh hanya mendengarkan sebuah penjelasan namun juga aktif dalam peran serta membuat proses pembelajaran di kelas menjadi kondusif.

Artinya Model Pembelajaran cooperative learning tipe group investigation efektif digunakan dalam pembelajaran menulis sehingga memberikan kontribusi yang positif terhadap kemampuan menulis teks cerita fantasi siswa dengan demikian keberhasilan belajar siswa akan tercapai secara optimal. 
Selain penggunaan Model Pembelajaran cooperative learning tipe group investigation yang menjadi pendukung terciptanya keaktifan siswa dalam proses pembelajaran dan memberikan keberhasilan siswa dalam proses belajar mengajar juga dipengaruhi oleh motivasi.

Motivasi belajar adalah seluruh daya penggerak di dalam diri siswa yang menimbulkan kegiatan belajar, yang menjamin kelangsungan dari kegiatan belajar dan memberi arah pada kegiatan belajar, sehungga tujuan yang dikehendaki oleh subjek belajar itu dapat tercapai. Peranan motivasi antara lain belajar menentukan tingkat berhasil atau gagalnya kegiatan siswa.

Berdasarkan uraian di atas, maka tingkat keberhasilan belajar siswa dalam suatu proses pembelajaran selain dipengaruhi oleh Model Pembelajaran cooperative learning tipe group investigation yang digunakan oleh guru dalam penyampaian materi dipengaruhi juga oleh faktor motivasi belajar siswa untuk mengikuti proses pembelajaran menulis teks cerita fantasi.

Artinya motivasi belajar siswa baik interinsik maupun ekstrinsik mempengaruhi kemampuan menulis siswa selain itu, pendekatan pembelajaran yang tepat juga mampu membantu siswa untuk memahami konsep materi yang diberikan oleh guru sehingga tingkat keberhasilan belajar siswa dalam proses pembelajaran akan tercapai dengan optimal.

Fiksi sendiri memiliki artian ketidaknyataan yang artinya jika dikaitkan dengan sebuah jalan cerita atau karangan maka segala sesuatu yang ada dalam cerita jika dikategorikan sebagai karangan fiksi maka cerita tersebut dipandang hanya bualan atau tidak akan ada di kehiupan nyata pada umumnya.
Cerita fantasi adalah cerita yang menampilkan tokoh, alur, latar, atau tema yang derajat kebenarannya diragunakan, baik menyangkut (hampir) seluruh maupun hanya sebagian cerita (Nurgiyantoro, 2012:295). Dalam sumber yang sama, cerita fantasi menurut Huck dkk adalah cerita yang memiliki makna lebih dari sekedar yang dikisahkan.

Cerita fantasi tidak hanya berkisah mengenai tokoh yang terkait dengan masa lalu saja, namun cerita fantasi itu sendiri karangan yang tercipta akibat daya pikir atau khayal seorang penulis sehingga membuat cerita menjadi lebih menyenangkan dan lebih mengasyikan ketika dibaca ataupun didengarkan.

Cerita fantasi juga merupakan salah satu ragam sastra anak yang membahas persoalanpersoalan yang dipahami oleh anak. Tingkat intelektual peserta didik berkonsentrasi pada bagian isi cerita yang dapat diterima oleh logika peserta didik.

Hal yang tidak mungkin menjadi mungkin sehingga dapat diterima dalam penciptaan cerita fantasi. Cerita ini pun dapat dijadikan ajang pengembangan daya kreatifitas yang dimiliki seorang anak dalam mengembangkan ide-ide yang akan ia tuangkan kedalam sebuah cerita.

Menulis cerita fantasi bisa membantu anak dalam mengembangkan daya fantasi yang menyebabkan timbulnya pola pikir yang baik, munculnya ide dalam membentuk rangkaian cerita yang menjadi satu kesatuan yang dapat diminati oleh individu khususnya para peserta didik.

Kita harus dapat membimbing anak-anak untuk mengembangkan daya imajinasinya ketika daya imajinasinya berjalan maka pola pikir juga akan mengalami sebuah perubahan yang cukup baik dan dapat membantu terbentuknya karakter dengan daya kreatifitas berpikir yang baik.

\section{SIMPULAN}

Berdasarkan hasil penelitian dan 
pembahasan, maka dapat ditarik kesimpulan seperti yang dipaparkan di bawah ini. Model pembelajaran cooperative learning tipe group investigation berpengaruh terhadap kemampuan menulis teks cerita fantasi siswa kelas VII SMP Negeri 21 Palembang.

Hal ini terbukti dari hasil pengujian hipotesis diperoleh bahwa nilai sig (2-tailed) sebesar 0,000. Karena nilai sig (probabilitas) lebih kecil dari 0,025, maka Ha diterima.

Motivasi belajar berpengaruh terhadap kemampuan menulis teks cerita fantasi siswa kelas VII SMP Negeri 21 Palembang. Hal ini terbukti dari hasil pengujian hipotesis diperoleh bahwa nilai sig (2-tailed) sebesar 0,020 Karena nilai sig (probabilitas) lebih kecil dari 0,025, maka Ha diterima.

Model Pembelajaran cooperative learning tipe group investigation dan motivasi belajar berpengaruh terhadap kemampuan menulis teks cerita fantasi siswa kelas VII SMP Negeri 21 Palembang. Hal ini terbukti dari hasil pengujian hipotesis diperoleh bahwa nilai probabilitas interaksi Model Pembelajaran cooperative learning tipe group investigation dan motivasi $(0,024)<0,05$; maka Ho ditolak dan Ha diterima.

\section{DAFTAR PUSTAKA}

Arikunto, Suharsimi. 2014. Prosedur Penelitian Suatu Pendekatan Praktik. Jakarta: Rineka Cipta.

Budiastuti. 2010. Peningkatan Motivasi Dan Keterampilan Menulis Puisi Dengan Penerapan Pendekatan Kontekstual Pada Siswa Sekolah Dasar. Jurnal online Google scholar. Diaksess 09 juli 2019.

Dalman. 2018. Keterampilan Menulis. Depok: PT. Raja Grafindo Persada.

Departemen Pendidikan Nasional. 2008. Kamus Besar Bahasa Indonesia. Jakarta: PT Gramedia Pustaka Utama.
Fitriana, Laila. 2010. Pengaruh Model Pembelajaran Cooperative Tipe Group Investigation (Gi) Dan Stad Terhadap Prestasi Belajar Matematika Ditinjau Dari Kemandirian Belajar Siswa. Jurnal online Google scholar. Diaksess 09 juli 2019. Hamdani. 2010. Strategi Belajar Mengajar.

Bandung: Pustaka Setia.

Hamalik, Oemar. 2015. Kurikulum dan

Pembelajaran. Jakarta: Bumi Aksara.

Kementerian Pendidikan dan Kebudayaan.

2016. Bahasa Indonesia Wahana

Pengetahuan. Jakarta: Kementerian

Pendidikan dan Kebudayaan

Kementerian Pendidikan dan Kebudayaan.

2014. Bahasa Indonesia Ekspresi Diri dan

Akademik. Jakarta: Kementerian

Pendidikan dan Kebudayaan.

Nurgiyantoro, Burhan. 2013. Penilaian

Pembelajaran Bahasa Berbasis

Kompetensi. Yogyakarta : BPFE

Yogyakarta.

Sardiman. 2014. Interaksi dan Motivasi Belajar

Mengajar. Jakarta : PT RajaGrafindo

Persada.

Shoimin, Aris. 2014. 68 Model Pembelajaran Inovatif dalam Kurikulum 2013. Jakarta: AR-RUZZ Media.

Siswanto, Wahyudi. 2017. Model Pembeljaran Menulis Cerita. Jakarta: Aditama.

Suprijono, Agus. 2013. Cooperative Learning. Yogyakarta: Pustaka Pelajar.

Sugiyono. 2016. Metode Penelitian Pendidikan. Bandung: Alfabeta.

Tarigan, Henry Guntur. 2008. Menulis Seba gai Suatu Keterampilan Berbahasa. Bandung: Angkasa.

Tarigan, Henry Guntur. 2008. Menyimak Sebagai Suatu Keterampilan Berbahasa. Bandung: Angkasa. 
Tim Edukatif. 2013. Mahir Berbahasa Indonesia. Jakarta: Erlangga.

Wardarita, Ratu.2014. Kemampuan Menulis Karya IImiah. Paraton:Solo 